\title{
SUGGESTIVE MATERIAL AS AN ASPECT OF STYLISTIC IMPLICATION OF ENGLISH ADVERTISING DISCOURSE (BASED ON AMERICAN TV COMMERCIALS)
}

S. Baranova, PhD in Philology, Associate Professor; https://orcid.org/0000-0001-9425-9774

\section{A. Trofymenko, Student}

Sumy State University,

2, Rymskogo-Korsakova St., Sumy, 40007, Ukraine

E-mail: svitlanabaranova@gmail.com; trofimenko.nastia@yandex.ua

The article deals with suggestion as a communicative aspect of implication extrapolated by various stylistic devices in English television commercial advertisements, namely the use of those devices that can be equalised with implicatures concerned with creating suggestive material. It shows detailed analysis of stylistic devices employed in advertising to diversify the connotations of a product by creating implicit, suggestive meanings and connotative fields for the product that is being advertised. Particular attention is paid to the presence of suggestion as a verbal factor in forming the text of a commercial just as well as it is conveyed visually. The focus is on further proving that implications in advertisement discourse rely on suggestive stylistic material to perform the manipulative function of any commercial.

Keywords: advertisement; suggestion, implication, stylistic devices, advertising discourse. https://doi.org/10.21272/Ftrk.2018.10(3)-02

Introduction. Due to the momentum of modern technology and science ever speeding up, the communicative processes, that linguistics is concerned with, grow ever faster as well. The concept of communication is now viewed from a very wide angle of different media outlets and the materials available for potential readers that connect via the media outlet. One of such outlets, interconnected to many ways of life, can cause a prominent reaction out of the receiving end in such a spontaneous and expressive way that it attracted a huge interest both out of specialist field as well as linguists. That outlet is advertising.

The sheer amount of advertisements produced daily raises a number of questions among the scientific community. Among the issues, there is the debate of explicit/implicit, reason of which is whether implication and suggestion are present during information conveyance in advertisement discourse [7, c. 102].

The notion of suggestion comes to communication theory from psychology. V. V. Zirka defines it as implicit guidance of adressee during communication, essentially manipulating them in the process of message decoding [6, c. 15]. By means of stylistic richness of the English language, the advertising adressers use this notion to override the fiction barrier created by the communication being consumer-orientated. Moreover, the role of advertising is significant enough for adressers to be creative in employing implication in stylistics, which this research is trying to prove.

The relevance of the study is due to general interest in discourse studies and connecting the modern branches of linguistics with other fields of science in researching a particular phenomenon that is advertised. The analysis of expressive means and stylistic devices used as suggestive material may help develop a better understanding of processes behind advertising as well as that psychological concept in general.

The objective of the article is to describe suggestive material contained in commercials that are framed in English advertising discourse via implication markers and stylistic markers.

Based on the objective, we can imply on tasks of the research:

1) to study the theoretical and practical implementations of suggestion;

2) to define and describe the process of implication that employs stylistic devices;

(C) S. Baranova, A. Trofymenko, 2018 
3) to clarify the use of suggestive material in advertisements for further research.

The subject matter is the suggestive material created by implication foregrounded in advertising discourse.

The specific topic of study is merging communication theory concept of implication and pragmatic branch of stylistics in search for suggestion as a verbal aspect.

Results of the research. The first stage of the research shows the analysis of the definitions of key concepts and notions by the scientific community. The represented discourse of advertising is defined by $\mathrm{O}$. V. Rebriy as a functional discourse that differs mainly by merging principles of informativeness with expression to create a pragmatic influence on addressee [3, c. 42]. This definition helps to connect the dots towards the manipulative function of commercials described by advertisements specialists. Implicit information, marked verbally and non-verbally (visually in our case), stands out as that core connection, hence the implications create an illusion of critical analysis for the potential consumer before they make their "involved" choice. Adding to that, implicative markers can create additional connotation fields for the product that is being advertised, indulging into social, diachronic criteria of communication which creates behavioural standards. G.G Pocheptsov describes these features of advertisement discourse as seemingly connecting ads to propaganda and other politically functional discourses [2, c. 72].

On this stage of a study we also have to clarify, which methods of research are being utilised and which parts of the media outlet concerned the connected discourse are specifically used. This study necessitates the use of stylistic qualitative analysis in connection with pragmatic linguistic synthesis and analysis of discourse. The sample of discourse at hand is being taken from American TV commercial ads, and the choice for that is based on the bulk of commercial adversiments having a larger degree of implicit information connected to the advertisements intention if compared to political or social ad texts. The two main goal groups that this part of advertising discourse is concerned about, the targeting on business success and the success of an ad product itself in the eyes of target audience, can be described as an extralinguistic factor and be put to use in the qualitative analysis done further in the study. O. E. Tkachuk-Miroshnichenko argues that implication markers in commercial ads help avoiding the explicit statements of voluntative ad function while tending to flavor the text as original and dynamic [5, c. 14].

Aforementioned suggestion continues into suggestive material - various insinuations and hints towards hidden benefits of advertised product, that are implied by the advert rather than explicitly stated, because in the case of direct point-out those benefits are often dismissed as unreliable, flawed or even made up by the addressee, the potential consumer. The precursor for forming this suggestive material is argued to be psychological, based on a polarization of context, an insinuation on lightening up the view of the product in the eyes of consumers [1, c. 59]. This is backed up by the fact that false advertising - explicit lies or misdirections about product's quality, quantity or guarantees of services are prohibited by U.S. law through Federal Trade Comission.

However, an emotive verbal suggestion is suitable for use in any advertising content. The process of suggestion is widely incorporated into American ads and provides a dampening of critical view in consumer's attention as well as lowering the chances that the addressee would compare the product to its competitors for a better choice. The concept of product comparison is the one that some advertisement agencies and copywriters tend to avoid while others use it to diversify their client base and lure in the clients of their competition by the so-called "comparative advertising". Comparative advertising is highly reliant on suggestion since it makes arguments in non-direct ways about the state of services or products provided by the competition. While the case of comparative advertising or "advertising wars" is mostly encouraged, the explicit disparaging of competing products or services in ad text is scrutinized, so the addressor of an ad must be drawing the suggestive comparisons very narrowly, in an attempt not to get liable.

On the second stage of the study the reasons for using stylistics in the matter of providing context to the notion of suggestion are specified. Specialist literature such as S. Moriarty's textbook on advertising states that the ad text has to fit in the suggestive 
material due to time restrictions (30 to 60 seconds of an ad window) and the general tendency of advertisements to minimize into short quips and slogans [9, c. 13]. Thus the implication markers are often implemented trough various stylistic devices and expressive means [4, c. 111]. The contextualisation of this in the following examples is done both to equalise those in the verbal aspect of suggestion and to review the stylistic devices as creative tools perform the menial tasks of advertising (informative, persuading, communicative functions) with an addition of expressive, affective function of advertisement text.

The nominative status of implication markers that form the suggestive material is divided into three categories:

1) lexical markers which convey the enrichment of a particular discourse in a language;

2) grammatical markers which provide further shortenings and anthropocentric cognitive means to the discourse at hand;

3) non-verbal markers which commit to imply through audiovisual cues, thus bearing an extralinguistic factor.

The correlation between these markers and expressive means comes from their continuous use in the speech of certain communicative groups within all language users, in our case, advertising adressors and potential consumers. Taking the notion of discourse persisting as a restricted communicative space that follows its own language patterns [8, c. 23], we can equalise the verbal implication markers and stylistic devices on the basis of advertising discourse being its own language within English.

With this in mind, we can conduct a list of conventionally defined stylistic devices (syntactic, lexical and semantic) that are used as implicative markers more often than others:

1) ellipsis that provides grammatical implication of decoding;

2) cliché and intertextuality that provide lexical and non-verbal implication;

3 ) rhetorical questions that provide grammatical implication of absence of addressee;

4) occasionalism in choice of words that provide lexical implication;

5) simile that provides lexical implication.

The following examples represent those stylistic devices in work of suggesting a variety of conditioned qualities and connotations toward the advertised products.

1. Chop-chop-chop, chop the tree, more than thirst you feel hungry, craving more than an ice-cold brew, reach for a can of Dinty Moore Stew. *whistling* Push real hard for that Stewskie, look at the beef and that gravy. This hardy meal is a real good deal, Dinty Moore is the beer of meals!

The soup advertisement in example (1) realizes the entertaining potential of English rhymimg while using a simile of the canned soup to beer or brews that maintains the suggestion of positive connotations. The target audience would gather that the soup is easy to open and quick to consume just like a can of beer. This suggestion is further strengthened by the occasionalism "Stewskie" which is formed from the similar sounding words "stew" and "brewskie" (a slang word for "beer"). The logical climax of the song "beer of meals" rhymes with a suggestive choice of words "real good deal" that can be decoded by the viewer as comparison to other products on the market. This example proves the creative function in verbal aspect of suggestion.

2. Last Thanksgiving 2 million people tried to deep-fat fry their turkey. 15 succeeded in setting their house on fire. At Christmas, there was a lot of driving over the river and through the woods and a little bit of skidding on the ice. So while you're celebrating Allstate would be standing by. Trouble never takes a holiday, neither should the insurance. Are you in good hands?

The insurance company ad in example (2) feeds into intertextuality of traditional American holidays: Thanksgiving Day and Christmas. The cliché situation both explicitly and implicitly states about the danger of such festivities, suggesting a better service to protect the potential clients. The last two sentences, a metaphorical antithesis plus simile of comparing trouble to an insurance group and the rhetorical question-slogan "Are you in good hands?" suggest the view on quality-assured and always-available service provided by

«Філологічні трактати», Том 10, № 3 ' 2018 
the company. This example solidifies the social, affective function in verbal aspect of suggestion

3. - I'm really looking forward to getting mine every month...

- You still get yours, grandma?

- Sure do!...

- I'd invite you up but I've just... got my Book of the Month.

The book delivery service ad in example (3) extends the process of decoding the advertising text by using ellipsis with the word "yours". This subverts the expectation of the viewer, suggesting something that isn't advertised and in connection with the visual cues creates false clichés in addressee's perception. This is called a "negative suggestive stimuli" and it is taken into consideration by the advertisers when the product is hard to advertise in visuals, such as a book delivery service. The deliberate subversion concentrates attention of the viewer on decoding the real message during the ad and then a sudden reveal of explicit slogan is taken less compulsively, without a negative reaction from the viewer. This example portrays the informational function and the function of viewer engagement in verbal aspect of suggestion, as well as the fact that suggestive implications are not always positive when trying to reach the desired advertising effect.

Despite the differences in levels of effectiveness the suggestive material is provided in each of the sampled ads, it definitely prospects in the goals of the study. The richness of stylistic and expressive devices fulfills an important task in the process of forming suggestive material via different verbal functions while simplifying the matter for an addressor to implicitly manipulate his target audience.

Conclusions. The advertising in general is a structured phenomenon that implements a number of tactics to functionally inform and drive in the potential consumers. The process of creating suggestive material is a relevant creative tool in planning out an advertisement campaign or forming a one-off ad for any company. This fact also makes it a relevant topic for further potential research.

The media outlet of ads gains great benefits by means of stylistic richness and expressiveness and the impact of implication in communication. The presence of examples proves the existence of implication and suggestion in the frame of advertising discourse and their connection with one another as built-in concepts. Suggestive material in an ad is structured upon multiple implicative markers that correlate with stylistic devices to add bigger positive effects towards the advertisements goals.

The theoretical and practical potential of verbal suggestive material is important not only for studies in the frame of advertising discourse but to practical studies as whole. The prospects of research include writing up a study on more narrow, specific substructures in the advertising discourse or taking a wider path with looking at other types of advertising such as social ads or political ad campaigns. Another path for future studies would be implementing comparisons between implication of communication theory with other pragmatic branches of linguistics to reveal other connections similar to those of verbal aspect of suggestion with stylistics.

\section{СУГЕСТИВНИЙ МАТЕРІАЛ ЯК АСПЕКТ СТИЛІСТИЧНОӤ ІМПЛІКАЦІЇ В АНГЛОМОВНОМУ РЕКЛАМНОМУ ДИСКУРСІ (НА МАТЕРІАЛІ АМЕРИКАНСЬКОЇ ТЕЛЕВІЗІЙНОЇ РЕКЛАМИ)}

С. В. Баранова, канд. філол. наук, дочент;

А. Трофименко, студентка

Сумський державний університет,

вул. Римського-Корсакова 2, м. Суми, Украӥна

E-mail: svitlanabaranova@gmail.com; trofimenko.nastia@yandex.ua

Подана стаття розглядає сугестію як комунікативний фактор імплікаиії, що поширюється в англомовній телевізійній рекламі завдяки використанню різноманітних стилістичних засобів, а саме тих засобів, що ототожнені з імплікаційними маркерами, які власне і утворюють сугестивний матеріал. Робота передбачає детальний аналіз стилістичних експресивних прийомів, використаних в рекламі з метою формування нових конотачій для продукту через створення прихованих, навіяних значень та конотаційних полів для продукту, що рекламується. Особлива увага приділяється присутності навіювання як вербального фактору у формуванні рекламного тексту на одному рівні з візуальною передачею сугестї. Доводиться, чо імплікачія в рекламному дискурсі базується на сугестивному стилістичному матеріалі для виконання маніпулятивної функиї реклами. Значна увага також 
приділясться поняттю сугестивного матеріалу як такого, що передає переваги товару лише імпліцитними маркерами, адже у випадку прямої мови увага адресата буде зосереджена на можливих недоліках товару або послуги.

У роботі теоретично та практично досліджується застосування сугестії в телевізійній рекламі, практично доводиться використання імплікаиії та сугестії в рекламі, висвітлюеться їх тіснии зв'язок, визначається та описується процес імплікачї, під час якого використовуються стилістичні прийоми.

Актуальність дослідження телевізійної реклами зумовлена спрямованістю лінгвістики на детальне вивчення проблем синтезу функиій односторонньої та двосторонньої масової комунікації, ефективност стилістичних мовних одинииь у вербальному компоненті комунікачії та їх інтерпретачії комунікантами.

Ключові слова: реклама, сугестія/навіювання, імплікація, стилістичні засоби, рекламний дискурс

\section{СУГГЕСТИВНЫЙ МАТЕРИАЛ КАК АСПЕКТ СТИЛИСТИЧЕСКОЙ ИМПЛИКАЦИИ В АНГЛОЯЗЫЧНОМ РЕКЛАМНОМ ДИСКУРС (НА МАТЕРИАЛЕ АМЕРИКАНСКОЙ ТЕЛЕВИЗИОННОЙ РЕКЛАМЫ)}

С. В. Баранова, канд. филол. наук, доцент;

А. Трофименко, студентка

Сумский государственный университет,

ул. Римского-Корсакова, 2, г. Сумы, Украина

E-mail: svitlanabaranova@gmail.com; trofimenko.nastia@yandex.ua

Данная статья рассматривает сугzестию как коммуникативный фактор импликации, который распространяется в англоязычной телевизионной рекламе через использование разнообразных стилистических фигур речи, а именно тех фигур речи, которые отождествляются с маркерами импликачии, создаюшими суггестивный материал. Работа включает в себя детальный анализ стилистических экспрессивных фигур речи, которые были использованы в рекламе с иелью формирования новых коннотаций для продукта при помощи создания скрытых значений, которые внушают присутствие новых коннотативных полей для рекламируемого продукта. Особенное внимание уделяется присутствию внушения как вербального фактора в создании рекламного текста наравне с визуальнои передачей данного фактора. Работа ставит перед собой цель в дальнейшем доказать, что импликация в рекламном дискурсе основана на сугzестивном стилистическом материале, который исполняет манипулятивную функиию рекламы.

Ключевые слова: реклама, сугzестия/внушение, импликация, стилистические фигуры речи, рекламный дискурс.

\section{REFERENCES}

1. Parshyn P. B. (2000). Rechevoe vozdejstvye: osnovnye sfery i raznovidnosti. Reklamnnii tekst : lyngvystyka $i$ semiotika. Moscow, Russia. S. 55-75.

2. Pocheptsov G. G. (2009). Theory of communication. [2 ed, expanded]. Moscow, Russia : SmartBuk. 651 p.

3. Rebriy O. V. (2003). Pragmatical aspect of translation of advertisement texts. Visnyk Kharkivskogo Nacionalnogo universitetu im. V. N. Karazina. Kharkiv, Ukraine, № 609, PP. 41-45.

4. Slushayenko V. Ye., Syeryk M. P. (2012). Slogan yak instrument social noyi reklamy. Visnyk NTUU "KPI". Politologiya. Sociologiya. Pravo : zbirnyk naukovyx pracz'. N 3 (15), S. 118-121.

5. Tkachuk-Miroshnychenko O.E.(2001). Implication in advertising discourse (based on English commercial advertisements) : doctoral thesis: 10.02.04. Kyiv, Ukraine, $201 \mathrm{p}$.

6. Zirka V. V. (2005). Language paradigm of manipulation in advertising: doctoral thesis in philological sciences: 10.02.02. Dnepropetrovsk, Ukraine, $462 \mathrm{p}$

7. Cook G. (2006). The Discourse of Advertising . - [2nd ed.]. London and New York : Routledge, 256 p.

8. T. A. van Dijk (1998). News as Discourse. Hillsdale, New Jersey : Erlbaum, 210 p.

9. William D. Wells, Sandra Moriarty, John Burnett (2005). Advertising: Principles and Practice (7th edition). New Jersey : Prentice Hall, 624 p.

10. Real time ad-analytics service iSpot.tv. - URL: https://www.ispot.tv/

\section{СПИСОК ВИКОРИСТАНИХ ДЖЕРЕЛ}

1. Паршин П. Б. Речевое воздействие: основные сферы и разновидности / П. Б. Паршин // Рекламный текст : лингвистика и семиотика. - М., 2000.- С. 55-75.

2. Почепцов Г. Г. Теория коммуникации / Г. Г. Почепцов. - [2-е изд., доп.]. - Москва, Россия, 2009 Издательство “СмартБук”. - 651 с.

3. Ребрій О. В. Прагматичний аспект перекладу рекламних текстів / О. В. Ребрій // Вісник Харківського національного університету ім. В. Н. Каразіна. - 2003. - № 609. - С. 41-45.

4. Слушаєнко В. Є. Слоган як інструмент соціальної реклами / В. Є. Слушаєнко, М. П. Сєрик // Вісник НТУУ “КПІ”. Політологія. Соціологія. Право. - 2012. - № 3 (15). - С. 118-121.

5. Ткачук-Мірошниченко О. Є. Імплікація в рекламному дискурсі (на матеріалі англомовної комерційної реклами): дис.. кандидата філол. наук: 10.02.04.- Київ., 2001.-201 с.

6. Зирка В. В. Языковая парадигма манипулятивной игры в рекламе: дисс. доктора филол. наук: 10.02.02 / Вера Васильевна Зирка. - Днепропетровск, 2005. - 462 с.

7. Cook G. The Discourse of Advertising / G. Cook. - [2nd ed.]. - London and New York : Routledge, 2006. - 256 p

8. van Dijk T. A. News as Discourse / T. A. van Dijk. - Hillsdale, New Jersey : Erlbaum, 1998. - 210 p.

9. Wells W. D., Moriarty S., Burnett J. Advertising: Principles and Practice (7th edition). - New Jersey Prentice Hall, 2005. - 624 p.

10. Real time ad-analytics service iSpot.tv [Electronic resource] - Access mode: https://www.ispot.tv/

Received: 1 March, 2018

«Філологічні трактати», Том 10, № 3 ' 2018 